\title{
Jak na interdisciplinaritu?
}

\section{Vážení čtenáři,}

dovolte, abychom předmluvu letošního čtvrtého čísla Českého finančního a účetního časopisu věnovali krátké úvaze na téma interdisciplinárního př́ístupu, a to s hlavním zřetelem na jeho využití v jednom $\mathrm{z}$ průřezů, který je předmětem našeho fakultního výzkumu v oblasti ř́zení podnikatelských subjektů.

Zřejmá tendence progresivních firem koncipovat systém řízení na bázi multidimenzionálního pohledu na podnikatelský proces vede ke stále silnější integraci všech významných aspektů jeho cílevědomého ovládání; strategického, taktického i operativního horizontu, výkonového, odpovědnostního, zákaznického, teritoriálního i procesního průřezu, organizační, plánovací, kontrolní, motivační i informační funkce a také jeho naturálně věcné a hodnotové podstaty. Vzájemná provázanost jednotlivých průřezů má samozřejmě vliv i na vědecké zkoumání těchto tendencí $\mathrm{z}$ hlediska potřeb a možností jejich zobecnění a využití v praxi: zdá se, že v tomto ohledu hraje nejvýznamnější roli právě potřeba interdisciplinárního pohledu na zkoumanou realitu.

Domnívám se - a ústřední zaměření fakultního výzkumného záměru Rozvoj účetní a finanční teorie a její aplikace v praxi z interdisciplinárního hlediska to potvrzuje - že jde o tendenci, která je dnes pro svět teorie a zejména vysokých škol s vědecko-výzkumnými ambicemi a nesporným potenciálem, ale také s jejich strukturou předmětů, oborů, kateder a relativně úzce specializovaných odborníků, primárně orientovaných disciplinárně, velice naléhavá. Stručně a zjednodušeně převedeno do výše zmíněné oblasti řízení podniků: má smysl zkoumat úzce disciplinárně tuto oblast, pokud svět manažerů klade prŕmočarou otázku „Jak řídit podnik?“" aniž se zabývá tím, která z disciplín ho vede správným směrem?

Navzdory zvýšeným nárokům na interdisciplinární přistup se domnívám, že ano. Svět i jeho ekonomický, resp. podnikatelský rozměr jsou dnes př́liš složité na to, aby mohly být racionálně uchopeny jediným „všeobjímajícím“ pohledem; objektivní vznik disciplín vedl $\mathrm{v}$ minulosti $\mathrm{k}$ tomu, že jediná objektivní realita začala být zkoumána $\mathrm{z}$ různých hledisek, a umožnil tak její analýzu bohatším, různorodým způsobem. Je však zároveň skutečností, že v současném stadiu vývoje vyvolávají disciplinárně formulované závěry i potřebu zkoumání jejich vzájemných vazeb, př́činných a důsledných souvislostí, priorit a omezení; nutnost interdisciplinárního pohledu je v tomto smyslu o to významnější, že zasazení - byt' správných - poznatků a závěrů do nesprávných, neadekvátně zdůrazněných nebo naopak podceněných souvislostí je problémem, který je třeba eliminovat se stejnou naléhavostí jako úzce disciplinární pohled na zkoumanou realitu.

Není cílem naší úvahy hodnotit, do jaké míry se nám daří využívat interdisciplinární pohled v našich výstupech, a to přesto, že by tato analýza po téměř čtyřech letech řešení našeho výzkumného záměru stála jistě za zamyšlení. Předmětem naší pozornosti je spíše otázka, jak dosáhnout toho, aby interdisciplinární nadhled na zkoumanou realitu byl reálným př́nosem pro uživatele? Bez nároku na úplnost chceme upozornit na některé předpoklady takového efektivního nadhledu, které se nedaří vždy naplnit.

Tím základním je pravděpodobně požadavek, aby interdisciplinárnímu pohledu dominovala koncepční východiska, která vytvářejí obecný rámec pro zkoumání struktury i 
vzájemných vazeb nově nahlížené reality. Jakkoli je tento požadavek vcelku nerozporně přijímán, nelze přehlédnout skutečnost, že se někdy realizuje na základě zpětné vazby interdisciplinární, primárně však jevový pohled na nástroje a metody řízení je teprve následně analyzován pohledem na podstatu řízeného procesu, ačkoliv logika zkoumání by spíše vyžadovala posloupnost opačnou.

Je třeba zdůraznit, že uvedený námět se zdaleka netýká jen výzkumu na fakultě, škole nebo v České republice. I tak proslulé a celosvětově známé nástroje a metody ř́zení podniku jako jsou např. Controlling a Balanced Scorecard vznikaly na bázi pragmaticky kritického pohledu na nepř́iliš efektivně fungující praxi, aby se teprve po jejich - v zásadě pozitivním přijetí podnikovou praxí začaly zkoumat vztahy nejen $\mathrm{k}$ „tradičním“, do té doby používaným nástrojům a metodám, ale také $\mathrm{k}$ obecně teoretickým východiskům jako $\mathrm{k}$ teorii ř́zení, vlastnické teorii, teorii koalice a dalším. Bez ohledu na časovou posloupnost analýzy tohoto vztahu se však domníváme, že interdisciplinární nadhled jak na obecná východiska, tak i konkrétní nástroje, využívané v řízení podniku, je naprosto nezbytný pro zajištění vzájemné integrity mezi teoretickými výstupy a jejich praktickou aplikací - mimochodem dalším požadavkem, který je obsažen v názvu našeho výzkumného záměru.

Zřejmou, nikoliv však již nesporně pozitivní tendencí, provázející snahy o interdisciplinární pohled, jsou snahy o terminologické vymezení (definování) obecných modelů, zdůrazňujících různé stránky interdisciplinárního nadhledu. Nad úrovní relativně nerozporně vymezených disciplín jsou tak charakterizovány koncepce, aplikační př́ístupy, nástroje a metody, které vyvolávají potřebu důkladné analýzy: jde o př́stup, který přináší novou kvalitu při prosazování integrity $\mathrm{v}$ řízení podnikatelského procesu, nebo spíše o snahu autorů se zviditelnit novým názvem pro tradiční část systému řízení? Je „Beyond Budgeting“ skutečně revolucí ve smyslu ,podnik lze výrazně efektivněji ř́́dit bez propracované metodiky stanovení hodnotových cílových veličin“, nebo jde spíše o tradiční apel na aplikaci progresivních nástrojů a metod při tvorbě a využití rozpočtů? Je „Strategic Alignment“ novým př́stupem při zajišt'ování strategické konzistence mezi cíli podniku a jeho nižších odpovědnostních úrovní, nebo pouze jinými slovy vyjádřený požadavek na racionální, nicméně již obecně známé (byt' často v praxi obtížně aplikovatelné) řízení investičních odpovědnostních středisek? Je „Life Time Costing“ kvalitativně novým pohledem na vztah nákladové náročnosti produktu a jeho přidané hodnoty pro zákazníka, nebo novým nátěrem pro využití čisté současné hodnoty při hodnocení specificky vymezeného investičního projektu?

Domníváme se, že při hledání odpovědí na tyto a obdobné otázky se většina z nás shodne na tom, že pravda je takříkajíc „někde uprostřed“. Tento, zdánlivě neprríliš vědecký závěr má pravděpodobně svou obecnou oporu v dialektickém vývoji světa i našeho poznání - a to bez ohledu na to, zda ideu vývoje ve spirále vzájemných vztahů a protikladů akceptujeme pod tímto názvem nebo ho - jako pojem podezřele spojený s nálepkou čehosi podvědomě nepatřičného - nahrazujeme jiným. Pokud však jsou předmětem našeho interdisciplinárního zkoumání právě naznačené, zkratkou (či reklamním názvem?) vymezené koncepce, nástroje a metody nebo nám dokonce úroveň našeho vědeckého poznání dá schopnost formulovat výstup, o němž jsme přesvědčeni, že je nový, měli bychom ho podrobit testu ,v čem je nový“ a „v čem vychází již z poznaného“.

Úvahu na toto téma bychom pak měli zhodnotit nejen sami v sobě, ale také (a zejména) ve vztahu ke čtenářum. Často citovaný, ale ne vždy korektně využívaný systémový prrístup, vycházející z poznání, že každý systém má své okolí - nadsystém, který zkoumaný objekt ovlivňuje, má své cíle, funkce umožňující jejich dosažení a vnitřní strukturu subsystémů a 
prvků, jejichž originální propojení umožňuje synergicky naplňovat funkce systému, je - zdá se $-\mathrm{v}$ tomto smyslu pohledem, který odlišení akceptovaných, již rozpoznaných východisek, a nově formulovaných závěrů umožňuje dosti zřetelným způsobem.

Naše poslední úvaha nad nezbytností interdisciplinárního nadhledu se týká zdánlivě samozřejmého předpokladu jakékoliv naší aktivity - smyslu, racionality či účelovosti našeho vědeckého zkoumání. Zejména s ohledem na skutečnost, že předmětem našeho zájmu jsou informace - odraz reality, jehož nejdůležitějšími funkcemi jsou odstraňovat neurčitost a dát nám schopnost se kvalifikovaně rozhodovat v naší (mimo jiné i ekonomické) cestě životem bychom si měli uvědomit, že ne každý náš poznatek musí být nutně informací a že žádný náš poznatek není univerzálně využitelnou informací, relevantní pro řešení jakékoliv rozhodovací úlohy. Každý náš vědecký výstup by z tohoto hlediska měl začít odpovědí na otázky, komu je náš výstup určen a při řešení jakých rozhodovacích úloh může, resp. nemůže být využit.

Také v protikladu k uvedené úvaze lze najít řadu významných aktivit, u nichž se podle našeho názoru intenzívně řeší úvahy na téma „Jak ....“, aniž byly dostatečně vyjasněny nutně předcházející otázky „Proč ...“, „Pro koho ...“ a „Pro řešení jakých rozhodovacích úloh ...“. Jednou z takových nám blízkých činností jsou práce na harmonizaci informačních výstupư finančního účetnictví, jejichž výsledkem je řada úprav nejen systémů IAS/IFRS a US GAAP, ale návazně i národních legislativních úprav a standardních řešení. Obsahová šíře a intenzita těchto prací dnes vyžaduje značné úsilí jen k tomu, aby odborník vstřebal ohromné množství faktografie o minulosti, současnosti a budoucích variantách, věnovaných otázkám vymezení, oceňování a vykazování informací o př́slušné oblasti podnikové reality. Ani v přemíře těchto podkladů by však vědecké zkoumání tohoto vývoje nemělo zapomínat na základní otázky, spojené s řešením těchto projektů: kdo jsou primární uživatelé těchto účetních informací, jaké rozhodovací úlohy řeší a jaké informační zázemí jim pro řešení těchto úloh mohou poskytnout informace finančního účetnictví.

Naléhavost těchto otázek je dnes nesporná; $\mathrm{z}$ řady průvodních znaků je totiž zřejmé, že v těchto koncepčně uživatelských otázkách dnes nemají zcela jasno ani autority, odpovědné za tento projekt. Pouhý, poněkud laciný poukaz na nutnost harmonizace výstupů finančního účetnictví vědecky neobstojí. I Koncepční rámec IASB, který je v současnosti též předmětem aktualizace a harmonizačních snah (je otázkou, zda se s jeho zpracováním neměl celý projekt zahájit) zdůrazňuje, že „Potřebu srovnatelnosti nelze zaměňovat s pouhou unifikací ..." a že „Pro podnik není vhodné, aby ponechával svá účetní pravidla neměnná, pokud existují alternativy s vyšší relevancí a spolehlivostí".

Zdá se v tomto smyslu, že zejména pečlivé vymezení relevance je problémem, který významně ovlivňuje prridanou hodnotu nejen prací na uvedeném projektu, ale také našich vědeckých výstupů. Mějme proto také na paměti, že smyslem našich vědeckých aktivit není primárně rozšíření seznamu našich publikačních výstupů, ale zejména nalezení „zákazníka“ uživatele, kterého obohatíme z hlediska jeho přirozeně interdisciplinárních informačních potřeb.

prof. Ing. Bohumil Král, CSc.

člen redakční rady

Českého finančního a účetního časopisu

a vedoucí Katedry manažerského účetnictví

Vysoké školy ekonomické v Praze
Ing. Jaroslav Wagner, Ph.D.

člen Katedry manažerského účetnictví Vysoké školy ekonomické v Praze 